\title{
Mediators of Differences Between Employed and Unemployed in Life Satisfaction and Emotional Well-being
}

\author{
Filip Fors Connolly ${ }^{1}$ (D) Tommy Gärling ${ }^{2}$
}

Accepted: 12 October 2021 / Published online: 28 October 2021

(c) The Author(s) 2021

\begin{abstract}
Previous research has shown that the unemployed has lower life satisfaction than the employed but that their emotional well-being may not differ. The aim is to investigate the role of mediators with bearings on these differences between the employed and unemployed in emotional well-being compared to life satisfaction. Participants were 3,463 employed and 452 unemployed living in five Western countries. They answered questions in an online survey. The results showed that the employed had both higher life satisfaction and emotional well-being. Mediation analysis replicated previous results in that the relationship between unemployment and life satisfaction was mediated by financial satisfaction. The relationship with emotional well-being was mediated by satisfaction with time use which was higher for the employed than the unemployed. Financial satisfaction was also a mediator of the relationship with emotional well-being, both directly and through satisfaction with time use. Although the unemployed felt lower time pressure than the employed, this factor was not a strong mediator of the relationship with emotional wellbeing, neither directly nor through satisfaction with time use. A possible explanation for the differences in the results for emotional well-being is that a negative mood is less associated with work than found in previous research.
\end{abstract}

Keywords Unemployment $\cdot$ Subjective well-being $\cdot$ Life satisfaction $\cdot$ Emotional wellbeing $\cdot$ Mediation analysis

\section{Introduction}

A recurrent finding in previous research on subjective well-being (SWB) is that the life satisfaction of the unemployed is lower than that of the employed (Di Tella et al., 2001; Ervasti Venetoklis, 2010). The difference between the employed and unemployed is not

Filip Fors Connolly

filip.fors@umu.se

1 Department of Sociology, Umeå University, Norra Beteendevetarhuset, Vindarnas torg 1, Umeå, Sweden

2 Department of Psychology, University of Gothenburg, Göteborg, Sweden 
only found in cross-sectional studies but as well in panel studies showing a substantial drop in life satisfaction following unemployment (Krueger \& Müller, 2012; Lucas et al., 2004). However, in contrast to the results for life satisfaction (i.e., the cognitive component of SWB), in studies of the difference in emotional well-being (i.e., the affective component of SWB) between the employed and unemployed, the results are mixed with some studies finding higher emotional well-being among unemployed, some studies lower, and some studies no difference (Hoang \& Knabe, 2021). The discrepancy between life satisfaction and emotional well-being in relation to unemployment is the focus of this study. More specifically, the aim is to investigate mediators of these relationships with bearings on why the employed differs from the unemployed in life satisfaction and emotional well-being.

SWB has two distinct components (Busseri \& Sadava, 2011; Diener \& Suh, 1997; Tov, 2018). One is a cognitive judgment of satisfaction with life which is believed to most strongly be influenced by individuals' possessions of financial resources (Dolan et al., 2017; Kahneman et al., 2010; Luhmann et al., 2014). The other component is self-reported experiences of positive and negative affect, commonly combined in a difference measure of emotional well-being referred to as the affect balance (Diener et al., 1985; Kahneman, 1999). In general, unemployment reduces personal financial resources and therefore, ceteris paribus, life satisfaction. Hence, a difference in judgments of life satisfaction is expected between the employed and unemployed (Knabe et al., 2010). Previous studies (Ervasti \& Venetoklis, 2010; Luo, 2020) have shown that both perceived financial strain and financial satisfaction (i.e., satisfaction with the personal economy) partially mediates the relationship between unemployment and life satisfaction. Our first hypothesis (H1a) is that, as found previously, financial satisfaction is a mediator of the relationship between life satisfaction and unemployment. However, previous studies have not investigated whether financial satisfaction mediates the relationship between unemployment and emotional wellbeing. Emotional well-being is proposed to be less influenced than life satisfaction by economic resources since people seldom attend to their financial circumstances in everyday life (Kahneman et al., 2010). Low financial satisfaction associated with unemployment may still cause feelings of stress and insecurity (Hiswåls et al., 2017) affecting emotional well-being negatively. Thus, our second hypothesis (H1b) is that financial satisfaction is also a mediator of the relationship between emotional well-being and unemployment.

Several studies indicate that how time is used is a determinant of emotional well-being (Kahneman et al., 2006; Knabe et al., 2010). Studies of the employed and unemployed have for this reason commonly used the Daily Reconstruction Method (DRM) to measure emotional well-being (Knabe et al., 2010; Krueger \& Mueller, 2012). In this method (Kahneman et al., 2004), participants are asked to report time use and emotions during a previous day segmented into distinct episodes consisting of primary activities (e.g. working, doing household chores, eating meals, watching television). Feelings (to what extent participants felt, e.g., happy, sad, or stressed) during each activity are rated on numerical scales. According to DRM studies free-time activities are in general more enjoyable than working and work-related activities (Bryson \& MacKerron, 2017; Kahneman et al., 2010; Knabe et al., 2010). If the unemployed spend more time in enjoyable free-time activities than the employed (Knabe et al., 2010), unemployment would then presumably increase emotional well-being (Hoang \& Knabe, 2021). Knabe et al. (2010) refer to this as a "timecomposition effect" of unemployment. A negative mood due to being unemployed may still prevent the unemployed to fully enjoy otherwise enjoyable activities (Krueger \& Mueller, 
2012). Knabe et al. (2010) refer to this as a "saddening effect". Another possibility is that the wealthier employed afford to make free time more enjoyable (e.g. paying fees for entertainment) than the unemployed do (Kahneman \& Deaton, 2010; Killingsworth, 2021; Kushlev et al., 2015). Affording to pay others for doing less enjoyable free-time activities (e.g. doing household chores) furthermore saves time to spend on more enjoyable activities (Whillans et al., 2017). Satisfaction with time use should reflect the relative contribution of different everyday activities to emotional well-being. Accordingly, we propose as a third hypothesis (H2a) that satisfaction with time use is a mediator of the relationship between unemployment and emotional well-being. If satisfaction with time use in free time depends on personal financial resources as suggested, we further propose that financial satisfaction influences satisfaction with time use directly and emotional well-being indirectly. According to our fourth hypothesis (H2b), financial satisfaction mediates the relationship between unemployment and emotional well-being through satisfaction with time use.

Another important factor may be that the unemployed are under less time pressure when performing free-time activities than the employed are when performing work or workrelated activities. Several studies (Fors Connolly et al., 2020b; Gärling et al., 2016) show that time pressure and time stress have a negative association with emotional well-being and that this association is stronger for people high in neuroticism (Fors Connolly et al., 2020a). Time pressure is also found to be high in free time (Goodin et al., 2005; Haller et al., 2013), which at least in part depends on spillover from long work hours (Gärling et al., 2014; Hartig et al., 2003). Thus, having no work would possibly reduce time stress and therefore increase emotional well-being among the unemployed. Our fifth hypothesis (H3a) is that time pressure is an additional mediator of the relationship between unemployment and emotional well-being. Since time pressure may negatively influence enjoyable free-time activities directly and therefore indirectly emotional well-being, we also propose as a sixth hypothesis ( $\mathrm{H} 3 \mathrm{~b})$ that time pressure mediates the relationship between unemployment and emotional well-being through satisfaction with time use.

In summary, we compare employed to unemployed with respect to life satisfaction and emotional well-being with the aim of investigating (1) whether the difference in life satisfaction is solely mediated by financial satisfaction, and (2) whether the difference in emotional well-being is jointly mediated by financial satisfaction, satisfaction with time use, and time pressure. Figure 1 shows the six hypotheses we propose and test on survey data obtained from a large cross-country sample. The measure of emotional well-being is obtained by asking the employed and unemployed participants to make ratings of daily mood ("Have do you feel today?"). A daily mood measure would provide an unbiased time sample of feelings which are representative for a normal day of the group to which the employed or unemployed participants belong (Gärling, 2019; Olsson et al., 2017), ${ }^{1}$ and since not being associated with specified activities, it may give different results for emotional well-being than the DRM in previous research. We also ask the participants to rate their mood during the past week in order to obtain a measure of emotional well-being that may be less influenced by extraneous factors than daily mood measures may be. Life satisfaction and financial satisfaction are measured in ways done in previous research. Satisfaction with time use and time pressure are additional rating measures that we measure similarly to in previous studies.

$\overline{1}$ The replies to the survey questions were about equally distributed across weekdays. 


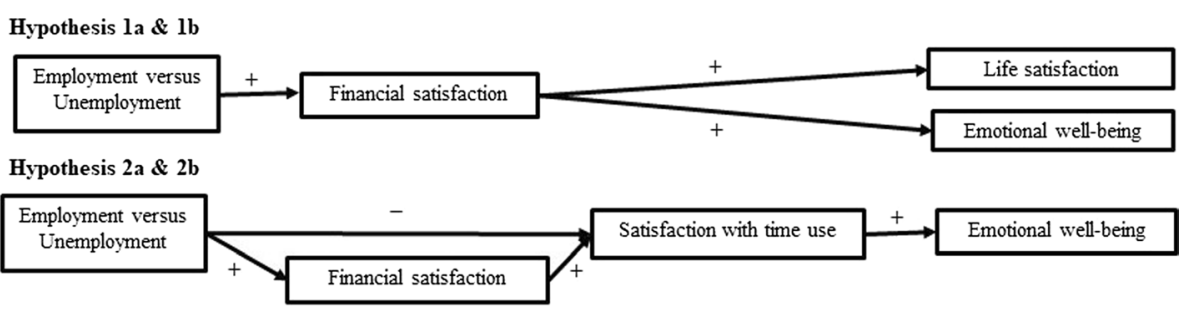

Hypothesis 3a \& 3b

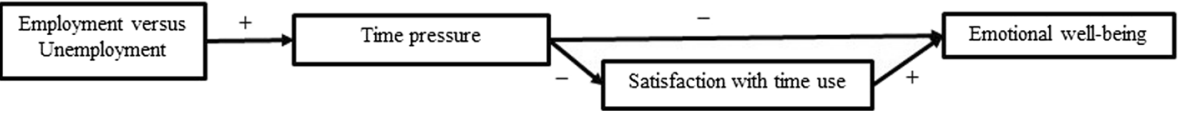

Fig. 1 Mediation hypotheses

\section{Method}

\subsection{Sample}

The study was part of a research project comparing subjective well-being between and within countries (e.g. Fors Connolly \& Johansson Säve, 2018). Participants were recruited from Qualtrics (http://www.qualtrics.com) online survey panels in Australia, Denmark, United Kingdom, United States of America, and Sweden. The data collection stopped when Qualtrics recorded 1,260 completed survey responses in each country. Three different attention checks were used in the survey to discard participants who did not fill out the questionnaire carefully. Furthermore, the sample is restricted to participants who were either employed or unemployed. This resulted in a total sample of 3915 participants consisting of 3463 employed and 452 unemployed (see selection criteria below). ${ }^{2}$

Table 1 shows descriptive statistics for the subsamples of employed and unemployed participants. The unemployed are more likely than the employed to be young, woman, single (compared to cohabiting), and to live in Australia or Sweden (compared to Denmark, UK, and USA). The unemployed also report a vastly lower net household income.

\subsection{Measures}

The online questionnaire administered to the participants had different modules including the following questions analysed in this study.

\subsubsection{Employment Status}

To assess participants' status in the labor market, we used the following question taken from the European Social Survey (https://www.europeansocialsurvey.org/docs/round7/field work/source/ESS7_source_main_questionnaire.pdf): "Which of these descriptions applies to what you have been doing for the last seven days?". Response categories included "paid

\footnotetext{
2 The number of unemployed was too few in the country samples to justify analyses of differences between countries.
} 
Table 1 Descriptive statistics for sociodemographic variables among employed $(n=3463)$ and unemployed $(\mathrm{n}=456)$ participants

\begin{tabular}{|c|c|c|c|c|c|}
\hline & & Empl & & Une & \\
\hline & & $\mathrm{n}$ & $\%$ & $\mathrm{n}$ & $\%$ \\
\hline Age (years) & $18-24$ & 302 & 8.7 & 104 & 23.0 \\
\hline & $25-34$ & 747 & 21.6 & 83 & 18.4 \\
\hline & $35-44$ & 833 & 24.1 & 81 & 17.9 \\
\hline & $45-54$ & 856 & 24.7 & 90 & 19.9 \\
\hline & $55-64$ & 572 & 16.5 & 85 & 18.8 \\
\hline & 65 or older & 153 & 4.4 & 9 & 2.0 \\
\hline Gender & Men & 1757 & 50.7 & 172 & 38.1 \\
\hline & Women & 1706 & 49.3 & 280 & 61.9 \\
\hline Household income (net) & $\$ 0$ to $\$ 24,999$ & 248 & 7.2 & 192 & 42.5 \\
\hline & $\$ 25,000$ to $\$ 49,999$ & 740 & 21.4 & 116 & 25.7 \\
\hline & $\$ 50,000$ to $\$ 74,999$ & 918 & 26.5 & 59 & 13,1 \\
\hline & $\$ 75,000$ to $\$ 99,999$ & 683 & 19.7 & 39 & 8.6 \\
\hline & $\$ 100,000$ or more & 874 & 25.2 & 46 & 10.2 \\
\hline Relationship status & Cohabiting & 2382 & 68.8 & 184 & 40.7 \\
\hline & Has partner not cohabiting & 238 & 6.9 & 47 & 10.4 \\
\hline & Single (no partner) & 843 & 24.3 & 221 & 48,9 \\
\hline Country of residence & Australia & 682 & 19.7 & 112 & 24.8 \\
\hline & Denmark & 692 & 20.0 & 78 & 17.3 \\
\hline & Sweden & 653 & 18.9 & 135 & 29.9 \\
\hline & United Kingdom & 727 & 21.0 & 70 & 15.5 \\
\hline & United States of America & 709 & 20.5 & 57 & 12.6 \\
\hline
\end{tabular}

work", "unemployed and actively looking for a job", "unemployed, wanting a job but not actively looking for a job", and other categories ("education", "permanently sick or disabled", "retired", "doing housework, looking after children or other persons"). For the analysis we use the data of individuals who were in paid work or were unemployed. To obtain a large enough sample, the two unemployed categories were merged. ${ }^{3}$

\subsubsection{Life Satisfaction}

Life satisfaction was assessed using three items from the Satisfaction With Life Scale (SWLS) (Diener et al., 1985; Pavot \& Diener, 2008). Participants indicated their agreement to the following statements: "In most ways my life is close to my ideal", "The conditions of my life are excellent", and "I am satisfied with my life". Agreement to these statements were rated on a 5-point scale ranging from 1 ("Strongly disagree") to 5 ("Strongly agree"). In addition to these items, a single-item question was included adopted from the European Social Survey: "All things considered, how satisfied are

\footnotetext{
${ }^{3}$ An additional analysis showed that participants in the pooled categories did not differ in life satisfaction or emotional well-being.
} 
you with your life as a whole nowadays?" Participants responded on a bipolar 7-point rating scale ranging from 0 to 6 with endpoints labelled "Extremely dissatisfied" and "Extremely satisfied."

\subsubsection{Emotional Well-being}

The main measure of emotional well-being was constructed from answers to the question "How do you feel today?" rated on a bipolar 7-point scale ranging from 0 to 6 with the endpoints labelled "In a very bad mood" and "In a very good mood". Ratings were also obtained on the same 0-to-6 scale in response to the question "How did you feel during the past week?" Measures of positive and negative affect were derived from six adjectives describing feelings taken from the Swedish Core Affect Scale (Västfjäll \& Gärling, 2007; Västfjäll et al., 2002) based on the affect circumplex (Russel, 1980, 2003; Yik et al., 2011). The participants indicated on 7-point 0-to-6 scales how frequently they experienced three positive feelings (engaged, happy, relaxed) and three negative feelings (worried, sad, bored) during the past week. The positively worded items were averaged to an index of positive affect and the negatively worded items were averaged to an index of negative affect.

\subsubsection{Financial Satisfaction}

In accordance with previous research (e.g. Joo \& Grable, 2004), financial satisfaction was measured with a single item. Participants rated the satisfaction with their "private financial situation" on a bipolar 7-point scale ranging from 0 ("Extremely dissatisfied") to 6 ("Extremely satisfied").

\subsubsection{Satisfaction with time use}

Satisfaction with time use was measured using a single question taken from Larsson et al. (2017). The question read: "If you think of how your time is divided between paid work, housework, commuting, sleeping, eating, exercising, socializing with family/ friends, and other leisure activities, how satisfied are you with the way your time is allocated among these different activities during your regular week?" Ratings were obtained on a 7-point scale ranging from 0 ("Not at all satisfied") to 6 ("Extremely satisfied").

\subsubsection{Time Pressure}

The measure of time pressure was obtained as agreement ratings to two statements selected from Gärling et al. (2016): "I frequently feel I do not have sufficient time"; "I often feel I need to hurry to be in time". The ratings were made on 5-point scales ranging from 1 ("Strongly disagree") to 5 ("Strongly agree").

\section{Results}

Descriptive statistics are shown in Table 2 separately for the employed and unemployed. The product moment correlations between the measures are also shown for the total sample. It can be seen that the daily mood ratings do not differ substantially from the ratings 


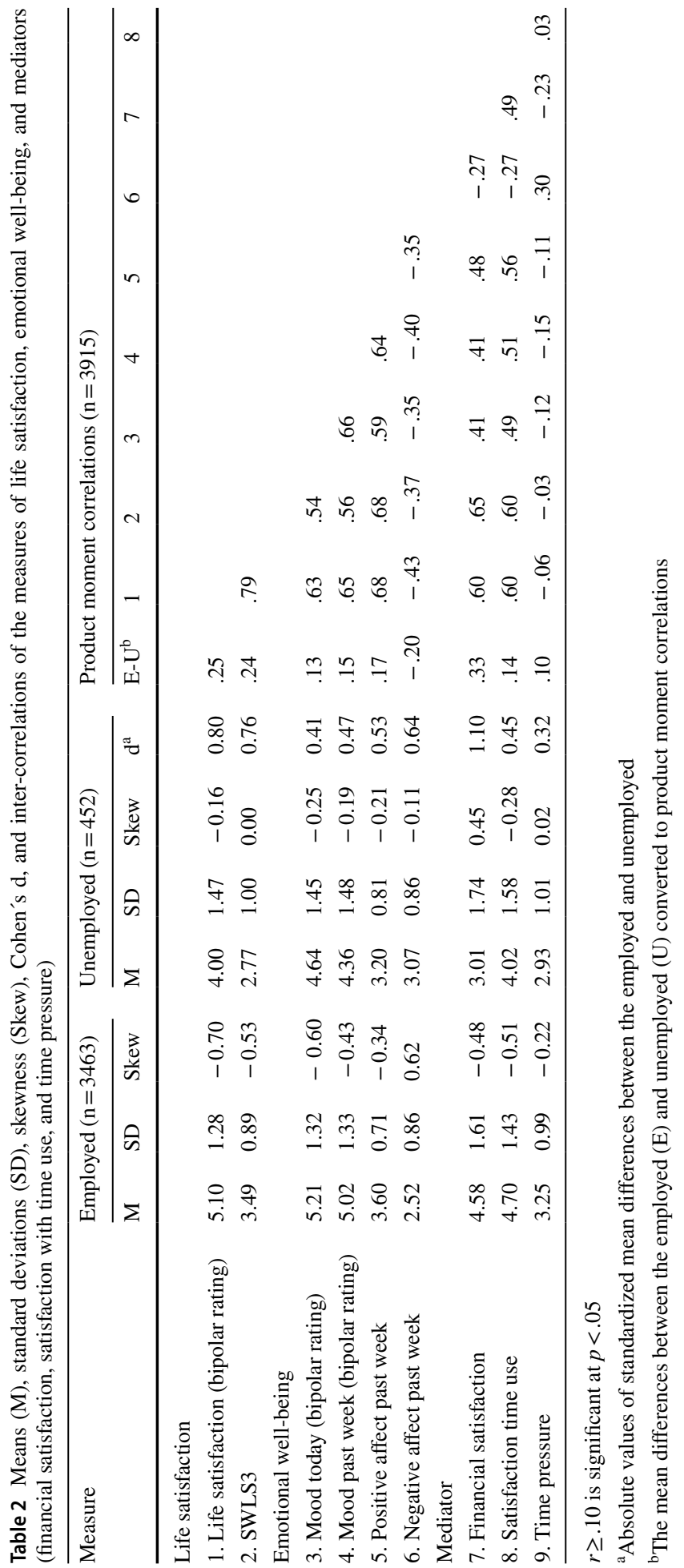




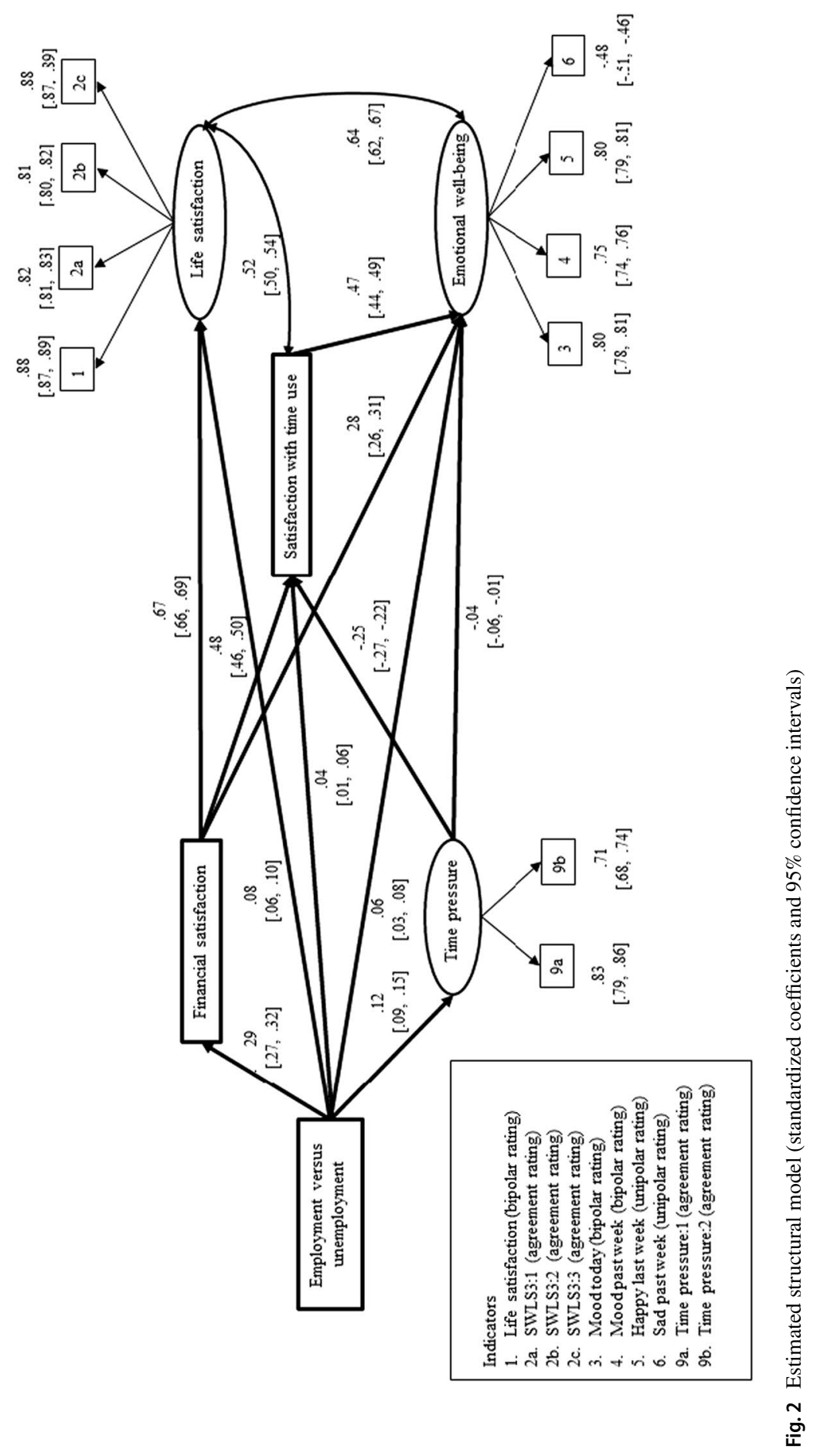


Table 3 Estimated indirect and total effects (standardized coefficients and 95\% confidence intervals)

\begin{tabular}{|c|c|c|c|c|}
\hline & \multicolumn{2}{|c|}{$\begin{array}{l}\text { Emotional well- } \\
\text { being }\end{array}$} & \multicolumn{2}{|c|}{$\begin{array}{l}\text { Life satisfac- } \\
\text { tion }\end{array}$} \\
\hline & $\beta$ & $95 \% \mathrm{CI}$ & $\beta$ & $95 \% \mathrm{CI}$ \\
\hline \multicolumn{5}{|l|}{ Hypotheses $1 \mathrm{a} \& 1 \mathrm{~b}$} \\
\hline $\begin{array}{l}\text { Employed vs. Unemployed } \rightarrow \text { Financial satisfaction } \\
\text { Hypotheses } 2 \mathrm{a} \& 2 \mathrm{~b}\end{array}$ & .08 & {$[.07, .09]$} & .20 & {$[.18, .22]$} \\
\hline $\begin{array}{l}\text { Employed vs. Unemployed } \rightarrow \text { Financial satisfaction } \rightarrow \text { Satisfaction } \\
\text { with time use }\end{array}$ & .07 & {$[.06, .07]$} & & \\
\hline $\begin{array}{l}\text { Employed vs. Unemployed } \rightarrow \text { Satisfaction with time use } \\
\text { Hypotheses } 3 \mathrm{a} \& 3 \mathrm{~b}\end{array}$ & .02 & {$[.01, .03]$} & & \\
\hline Employed vs. Unemployed $\rightarrow$ Time pressure & {$[-.00$} & {$[-.01,-.00]$} & & \\
\hline $\begin{array}{l}\text { Employed vs. Unemployed } \rightarrow \text { Time pressure } \rightarrow \text { Satisfaction with } \\
\text { time use }\end{array}$ & {$[-.01$} & {$[-.02,-.01]$} & & \\
\hline Total indirect effect & .15 & {$[.13, .17]$} & .20 & {$[.18, .22]$} \\
\hline Total effect & .21 & {$[.18, .24]$} & .28 & {$[.25, .30]$} \\
\hline
\end{tabular}

of mood during past week, and that both measures of life satisfaction do not differ substantially from each other. All means are higher in the employed than in the unemployed subsample except that the mean difference is reversed for negative affect. Cohen's $d$ (Cohen, 1988 ) is reported as a standardized measure of the size of the mean differences. The largest effects are observed for the measures of life satisfaction and financial satisfaction followed by the measures of emotional well-being and satisfaction with time use. The smallest effect is observed for time pressure. All $d$ s correspond to $t$-values that are significant at $p<0.05$. This is also shown as significant product moment correlations between the employed and unemployed differences and the measures. The correlations are furthermore high between the two measures of life satisfaction as well as between the measures of emotional wellbeing except that negative affect has weaker (negative) correlations with the other measures. Among the mediators, financial satisfaction has a positive correlation with satisfaction with time use and a negative correlation with time pressure. Satisfaction with time use and time pressure are not correlated.

The structural equation model in Fig. 2 was estimated using maximum-likelihood estimation $(\mathrm{M}+7.12)$ including the manifest variables employment versus unemployment, financial satisfaction, and satisfaction with time use, and the latent variables time pressure, life satisfaction, and emotional well-being. The indicators of life satisfaction are the single bipolar rating of life satisfaction (\#1) and the agreement ratings of the three statements in SWLS3 (\#2a, \#2b, $\# 2 c)(\alpha=0.90)$. The indicators of emotional well-being are the two mood ratings (\#3, \#4) and the unipolar affect ratings of happy and sad $(\# 5, \# 6)(\alpha=0.79)$. The remaining four affect ratings were not included since their low correlations with the other measures of emotional wellbeing substantially reduced $\alpha$. The indicators of time pressure (\#9a, \#9b) are the agreement ratings of the two statements $(\alpha=0.74)$.

To evaluate the structural model in Fig. 2, we used the standard fit statistics comparative fit index (CFI), root mean squared error of approximation (RMSEA), and standardized root mean residual (SRMR). All the indices are in the acceptable range $(\mathrm{CFI}=0.950$; $\mathrm{RMSEA}=0.080$, $95 \% \mathrm{CI}[0.076,0.083]$; SRMR $=0.045)$, suggesting that the hypothesized model fitted the data. 
Standardized coefficients and 95\% confidence intervals are shown in the figure for the direct effects implied by the hypotheses. It can be seen that all are significant.

In order to test the six hypotheses (Fig. 1), Table 3 reports indirect and total effects including $95 \%$ confidence intervals. All the indirect effects hypothesized to mediate the relationship between the difference between the employed and unemployed and life satisfaction or emotional well-being are significant. As expected (Hypothesis 1a), financial satisfaction mediates the relationship between unemployment and life satisfaction. In addition, supporting Hypothesis $1 b$ financial satisfaction is a single mediator of the relationship with emotional well-being. In support of Hypothesis $2 b$, financial satisfaction is also a mediator of the relationship with emotional well-being through satisfaction with time use, which in agreement with Hypothesis $2 \mathrm{a}$ is an additional single mediator of the relationship with emotional well-being. Time pressure did not have a strong negative direct effect on emotional well-being. Marginal significance is still observed for the negative indirect effect through time pressure as proposed in Hypothesis 3a, as well as the negative indirect effect through time pressure and satisfaction with time use as proposed in Hypothesis $3 b$.

\section{Discussion and Conclusions}

In this study, we find that the unemployed has lower life satisfaction than the employed as has been shown in previous research (Di Tella et al., 2001; Ervasti Venetoklis, 2010), but in contrast to some other studies (e.g. Knabe et al., 2010; Krueger \& Mueller, 2012) we also find that their emotional well-being is lower. The latter finding is true for all the measures of emotional well-being, including both ratings of mood on single bipolar scales as well as the unipolar ratings on multiple adjective scales of positive and negative affect. Our results also show that when compared to the employed survey participants, the unemployed are less financially satisfied. They are furthermore less satisfied with time use despite experiencing a lower time pressure.

We pursued additional analyses to investigate the hypothesized mediation of financial satisfaction, satisfaction with time use, and time pressure. These analyses confirm previous findings (Luo, 2020) in showing that financial satisfaction mediates the relationship between unemployment and life satisfaction. A new finding is that financial satisfaction mediates the relationship with emotional well-being, either directly, presumably by decreasing stress and insecurity (Hiswåls et al., 2017), or indirectly through satisfaction with time use, presumably by giving access to economic means necessary for engagement in enjoyable free-time activities (Kahneman \& Deaton, 2010; Killingsworth, 2021; Kushlev et al., 2015; Whillans et al., 2017). The results are less clear in showing the hypothesized role of time pressure (Fors Connolly et al., 2020a, 2020b; Gärling et al., 2016). Time pressure is, as expected, higher among the employed than the unemployed. Yet, the evidence that less time pressure increases emotional well-being is weak, neither that it directly reduces time stress or indirectly by increasing satisfaction with time use. A possible explanation is that time pressure primarily affects emotional well-being among individuals high in neuroticism (Fors Connolly et al., 2020a). Furthermore, time pressure sometimes improve performance and may for this reason have positive effects on satisfaction with time use and emotional well-being (Garhammer, 2002).

The results for the mediation of emotional well-being raise some questions about the time-disposition and saddening effects discussed in previous studies using the DRM to measure emotional well-being (Knabe et al., 2010; Krueger \& Mueller, 2012). In our study, 
satisfaction with time use was higher among the employed than the unemployed and mediates the difference in emotional well-being. Since the employed devotes more time to work and work-related activities than the unemployed, could this mean that work-activities are in fact enjoyable? Our results suggest that this may be the case. Furthermore, the findings are in line with a recent meta-analysis by Biskup et al. (2019) showing that in studies of experience sampling at work, positive affect is relatively higher and negative affect relatively lower.

In our measure of satisfaction with time use, the participants are asked themselves to rate if they are satisfied with how they dispose their time (Larsson et al., 2017). They may then use another aggregation rule than the objective summation in the DRM. This is an alternative account of the time-disposition effect (Knabe et al., 2010). A strength of our results is that we find that our measure of satisfaction with time use, as hypothesized, mediates the relationship between unemployment and emotional well-being. Furthermore, the hypothesized observed mediation through both financial satisfaction and satisfaction with time use suggests that the saddening effect also play a role. Our goal was however not to investigate the time-disposition and saddening effects, but primarily whether the relationships between unemployment and emotional well-being is mediated differently than the relationship between unemployment and life satisfaction. Although the results are not inconsistent with the time-disposition and saddening effects, we consider our mediation findings to be the main outcome of this research.

Our study may also have methodological implications. We note that our finding that emotional well-being is lower among the unemployed than the employed is consistent with the results of previous studies using retrospective measures of emotional well-being (Schimmack et al., 2008) as well as studies assessing the relationship between unemployment and mental health (e.g. McKee-Ryan et al., 2005). Although mental health and emotional well-being are different constructs, measures of mental health usually include items tapping negative and positive affect (Hu et al., 2007). Yet, our results do not mirror the results of previous studies that have measured emotional well-being with the DRM (Hong $\&$ Knabe, 2021). The DRM studies typically find no or a weak relationship between unemployment and emotional well-being (e.g. Knabe et al., 2010; Krueger \& Mueller, 2012). The question should then be raised what accounts for the differences between the results of the DRM studies and other studies such as ours? One possibility is that global measures of emotional well-being framed in relation to the past week, month, or year represent a cognitive evaluation of the period in question rather than a retrieval of past affective experiences. DRM studies on the other hand, is often thought to capture actual emotional experiences in the same way as experience sampling does (Bolger et al., 2003). However, we find a clear negative association between unemployment and emotional well-being even when using a measure (ratings of mood today) which should be less affected by memory distortions as well as less contaminated by cognitive evaluations. Diener and Tay (2013) recognize additional shortcomings of the DRM that may explain the differences. We suggest that in the DRM studies of unemployment, the results are influenced by stereotypical notions of how activities influence enjoyment (e.g. "watching TV is fun", "work is boring") rather than actual enjoyment (Lucas et al., 2020). This could thus potentially explain why the DRM studies tend to find no association between unemployment and emotional well-being and that unemployment has beneficial time-disposition effects. It could also explain why the DRM studies find substantially weaker associations between life satisfaction and emotional well-being than studies using global reports of well-being (Schimmack et al., 2008) or studies using experience sampling (Berlin \& Fors Connolly, 2019; Eid \& Diener, 2004). Our results thus suggest that future studies should investigate differences 
between unemployed and employed using other methods to capture emotional well-being, preferably experience sampling. Not the least since DRM and global measures have known shortcomings.

We acknowledge that our samples of employed/unemployed may not be fully representative of these groups in the general population since participants were not a random population sample. In particular, we note that the share of women among the unemployed is in our sample considerably larger than the share of men despite no such pattern existing in the official population statistics (OECD, 2016). However, this difference should not affect our mediation results.

This study makes two main contributions. First, in a large sample of participants from five different Western countries, the unemployed differs from the employed both in having lower life satisfaction and lower emotional well-being. This has not been unequivocally shown in previous research (e.g. Knabe et al., 2010; Krueger \& Mueller, 2012). Secondly, accounting for the results for emotional well-being, financial satisfaction (and therefore financial resources) is an important mediator of the difference in emotional wellbeing between the employed and unemployed, not only of the difference in life satisfaction. This is consistent with previous studies (Kahneman \& Deaton, 2010; Killingsworth, 2021; Kushlev et al., 2015; Whillans et al., 2017) showing that financial resources are used to reduce negative affect in daily encounters as well as to increase positive affect. We do not claim, however, that other mediators of the difference between employed and unemployed do not exist than those related to the personal economy that we have investigated. The research literature suggests many candidates such as self-esteem and social status (Kokko \& Pulkkinen, 1998), social support (Atkinson et al., 1986), and personal control (Creed \& Bartrum, 2008). We would also like to add: Many episodes during days filled with work may positively influence emotional well-being. An example is that acceptance of a paper for publication increases researchers' emotional well-being.

Funding Open access funding provided by Umea University.

\section{Declarations}

Conflict of interest The authors declare that there is no conflict of interest.

Open Access This article is licensed under a Creative Commons Attribution 4.0 International License, which permits use, sharing, adaptation, distribution and reproduction in any medium or format, as long as you give appropriate credit to the original author(s) and the source, provide a link to the Creative Commons licence, and indicate if changes were made. The images or other third party material in this article are included in the article's Creative Commons licence, unless indicated otherwise in a credit line to the material. If material is not included in the article's Creative Commons licence and your intended use is not permitted by statutory regulation or exceeds the permitted use, you will need to obtain permission directly from the copyright holder. To view a copy of this licence, visit http://creativecommons.org/licenses/by/4.0/.

\section{References}

Atkinson, T., Liem, R., \& Liem, J. H. (1986). The social costs of unemployment: Implications for social support. Journal of Health and Social Behavior. https://doi.org/10.2307/2136947

Berlin, M., \& Fors Connolly, F. (2019). The association between life satisfaction and affective well-being. Journal of Economic Psychology, 73, 34-51. https://doi.org/10.1016/j.joep.2019.04.010 
Biskup, M. J., Kaplan, S., Bradley-Geist, J. C., \& Membere, A. A. (2019). Just how miserable is work? A meta-analysis comparing work and non-work affect. PLOS ONE, 14(3), e0212594. https://doi.org/10. 1371/journal.pone.0212594

Bolger, N., Davis, A., \& Rafaeli, E. (2003). Diary methods: Capturing life as it is lived. Annual Review of Psychology, 54, 579-616. https://doi.org/10.1146/annurev.psych.54.101601.145030

Bryson, A., \& MacKerron, G. (2017). Are you happy while you work? Economic Journal, 127(599), 106125. https://doi.org/10.1111/ecoj.12269

Busseri, M. A., \& Sadava, S. W. (2011). A review of the tripartite structure of subjective well-being: Implications for conceptualization, operationalization, analysis, and synthesis. Personality and Social Psychology Review, 15, 290-314. https://doi.org/10.1177/1088868310391271

Cohen, J. (1988). Statistical power analysis for the behavioral sciences (2nd ed.). Erlbaum.

Creed, P. A., \& Bartrum, D. A. (2008). Personal control as a mediator and moderator between life strains and psychological well-being in the unemployed. Journal of Applied Social Psychology, 38(2), 460481. https://doi.org/10.1111/j.1559-1816.2007.00313.x

Di Tella, R., MacCulloch, R. J., \& Oswald, A. J. (2001). Preferences over inflation and unemployment: Evidence from surveys of happiness. American Economic Review, 91(1), 335-341. https://doi.org/10. 1257/aer.91.1.335

Diener, E., Larsen, R. J., Levine, S., \& Emmons, R. A. (1985). Intensity and frequency: Dimensions underlying positive and negative affect. Journal of Personality and Social Psychology, 48, 1253-1265. https://doi.org/10.1037/0022-3514.48.5.1253

Diener, E., \& Suh, E. (1997). Measuring quality of life: Economic social and subjective indicators. Social Indicators Research, 40, 189-216. https://doi.org/10.1023/A:1006859511756

Diener, E., \& Tay, L. (2013). Review of the day Reconstruction method (DRM). Social Indicators Research, 116(1), 255-267. https://doi.org/10.1007/s11205-013-0279-x

Dolan, P., Kudrna, L., \& Stone, A. (2017). The measure matters: An investigation of evaluative and experience-based measures of wellbeing in time use data. Social Indicators Research, 134(1), 57-73. https:// doi.org/10.1007/s11205-016-1429-8

Eid, M., \& Diener, E. (2004). Global judgments of subjective well-being: Situational variability and longterm stability. Social Indicators Research, 65(3), 245-277. https://doi.org/10.1023/B:SOCI.00000 03801.89195.bc

Ervasti, H., \& Venetoklis, T. (2010). Unemployment and subjective well-being: An empirical test of deprivation theory, incentive paradigm and financial strain approach. Acta Sociologica, 53(2), 119-139. https://doi.org/10.1177/0001699310365624

Fors Connolly, F., Johansson Sevä, I., \& Gärling, T. (2020). The bigger the better? Business size and small-business owners' subjective well-being. Journal of Happiness Studies. https://doi.org/10.1007/ s10902-020-00264-2

Fors Connolly, F., \& Johansson Sevä, I. (2018). Social status and life satisfaction in context: A comparison between Sweden and the USA. International Journal of Wellbeing, 8(2), 110-134. https://doi.org/10. 5502/ijw.v8i2.710

Fors Connolly, F., Johansson Sevä, I., \& Gärling, T. (2020a). How does time pressure influence emotional well-being? Investigating the mediating roles of domain satisfaction and neuroticism among smallbusiness owners. International Journal of Well-Being, 10(2), 71-88. https://doi.org/10.5502/ijw.v10i2. 805

Garhammer, M. (2002). Pace of life and enjoyment of life. Journal of Happiness Studies, 3, 217-256. https://doi.org/10.1023/A:1020676100938

Gärling, T. (2019). Travel-related feelings: Review, theoretical framework, and numerical experiments. Transportation Letters, 11(1), 54-62. https://doi.org/10.1080/19427867.2017.1300399

Gärling, T., Gamble, A., Fors, F., \& Hjerm, M. (2016). Emotional well-being related to time pressure, impediment to goal progress, and stress-related symptoms. Journal of Happiness Studies, 17(5), 17891799. https://doi.org/10.1007/s10902-015-9670-4

Gärling, T., Krause, K., Gamble, A., \& Hartig, T. (2014). Time pressure and emotional well-being. PsyCH Journal, 3, 132-143. https://doi.org/10.1002/pchj.52

Goodin, R. E., Rice, J. M., Bittman, M., \& Saunders, P. (2005). The time-pressure illusion: Discretionary time vs free time. Social Indicators Research, 73(1), 43-70. https://doi.org/10.1007/ s11205-004-4642-9

Haller, M., Hadler, M., \& Kaup, G. (2013). Leisure time in modern societies: A new source of boredom and stress? Social Indicators Research, 111(2), 403-434. https://doi.org/10.1007/s11205-012-0023-y

Hartig, T., Johansson, G., \& Kylin, C. (2003). Residence in the social ecology of stress and restoration. Journal of Social Issues, 59, 611-636. https://doi.org/10.1111/15404560.00080 
Hiswåls, A. S., Marttila, A., Mälstam, E., \& Macassa, G. (2017). Experiences of unemployment and wellbeing after job loss during economic recession: Results of a qualitative study in east central Sweden. Journal of Public Health Research, 6(3), 995. https://doi.org/10.4081/jphr.2017.995

Hoang, T. T. A., \& Knabe, A. (2021). Time use, unemployment, and well-being: An empirical analysis using british time-use data. Journal of Happiness Studies, 22, 2525-2548. https://doi.org/10.1007/ s10902-020-00320-X

Hu, Y., Stewart-Brown, S., Twigg, L., \& Weich, S. (2007). Can the 12-item general health questionnaire be used to measure positive mental health? Psychological Medicine, 37(7), 1005-1013. https://doi.org/10. 1017/S0033291707009993

Joo, S. H., \& Grable, J. E. (2004). An exploratory framework of the determinants of financial satisfaction. Journal of Family and Economic Issues, 25(1), 25-50. https://doi.org/10.1023/B:JEEI.0000016722. $37994.9 \mathrm{f}$

Kahneman, D. (1999). Objective happiness. In D. Kahneman, E. Diener, \& N. Schwartz (Eds.), Well-being: The foundations of hedonic psychology (pp. 3-25). New York: Russell Sage.

Kahneman, D., \& Deaton, A. (2010). High income improves evaluation of life but not emotional well-being. Proceedings of the National Academy of Sciences, 107(38), 16489-16493. https://doi.org/10.1073/ pnas. 1011492107

Kahneman, D., Krueger, A. B., Schkade, D., Schwarz, N., \& Stone, A. (2004). A survey method for characterizing daily life experience: The Day Reconstruction Method (DRM). Science, 306, 1776-1780. https://doi.org/10.1126/science. 1103572

Kahneman, D., Krueger, A. B., Schkade, D., Schwarz, N., \& Stone, A. A. (2006). Would you be happier if you were richer? A Focusing Illusion. Science, 312(5782), 1908-1910. https://doi.org/10.1126/science. 1129688

Kahneman, D., Schkade, D. A., Fischler, C., Krueger, A. B., \& Krilla, A. (2010). The structure of wellbeing in two cities: Life satisfaction and experienced happiness in Columbus, Ohio, and Rennes, France. In E. Diener, J. F. Helliwell, \& D. Kahneman (Eds.), International Differences in Well-being (pp. 16-33). Oxford University Press.

Killingsworth, M. A. (2021). Experienced well-being rises with income, even above $\$ 75,000$ per year. PNAS, 118(4), e2016976118. https://doi.org/10.1073/pnas2016976118

Knabe, A., Rätzel, S., Schöb, R., \& Weimann, J. (2010). Dissatisfied with life but having a good day: Timeuse and well-being of the unemployed. Economic Journal, 120(547), 867-889. https://doi.org/10. 1111/j.1468-0297.2009.02347.x

Kokko, K., \& Pulkkinen, L. (1998). Unemployment and psychological distress: Mediator effects. Journal of Adult Development, 5(4), 205-217. https://doi.org/10.1023/A:1021450208639

Krueger, A. B., \& Mueller, A. I. (2012). Time use, emotional well-being, and unemployment: Evidence from longitudinal data. American Economic Review, 102(3), 594-599. https://doi.org/10.1257/aer. 102.3.594

Kushlev, K., Dunn, E. W., \& Lucas, R. E. (2015). Higher income is associated with less daily sadness but not more daily happiness. Social Psychological and Personality Science, 6(5), 483-489. https://doi. org/10.1177/1948550614568161

Larsson, J., Andersson, D., \& Nässén, J. (2017). Subjective temporal well-being: Defining, measuring, and applying a new concept. Cogent Social Sciences, 3(1), 1306201. https://doi.org/10.1080/23311886. 2017.1306201

Lucas, R. E., Clark, A. E., Georgellis, Y., \& Diener, E. (2004). Unemployment alters the set point for life satisfaction. Psychological Science, 15(1), 8-12. https://doi.org/10.1111/j.09637214.2004.01501002.x

Lucas, R. E., Wallsworth, C., Anusic, I., \& Donnellan, M. B. (2020). A direct comparison of the day reconstruction method (DRM) and the experience sampling method (ESM). Journal of Personality and Social Psychology, Advance Online Publication. https://doi.org/10.1037/pspp0000289

Luhmann, M., Hawkley, C., \& Cacioppo, J. T. (2014). Thinking about one's subjective well-being: Average trends and individual differences. Journal of Happiness Studies, 17(5), 1789-1799. https://doi.org/10. 1007/s10902-013-9448-5

Luo, J. (2020). A pecuniary explanation for the heterogeneous effects of unemployment on happiness. Journal of Happiness Studies, 21(7), 2603-2628. https://doi.org/10.1007/s10902-019-00198-4

McKee-Ryan, F., Song, Z., Wanberg, C. R., \& Kinicki, A. J. (2005). Psychological and physical well-being during unemployment: A meta-analytic study. Journal of Applied Psychology, 90(1), 53-76. https:// doi.org/10.1037/0021-9010.90.1.53

OECD. (2016). Unemployment rates: As a percentage of labour force in Labour. Paris: OECD Publishing. https://doi.org/10.1787/factbook-2015-table114-en 
Olsson, L. E., Gärling, T., Ettema, D., Friman, M., \& Ståhl, M. (2017). Current mood and recalled impacts of current moods after exposures to sequences of potential monetary outcomes. Frontiers in Psychology: Cognition, 8, 66. https://doi.org/10.3389/fpsyg.2017.00066

Pavot, W., \& Diener, E. (2008). The satisfaction with life scale and the emerging construct of life satisfaction. The Journal of Positive Psychology, 3(2), 137-152.

Russell, J. A. (1980). A circumplex model of affect. Journal of Personality and Social Psychology, 39, 1161-1178. https://doi.org/10.1037/h0077714

Russell, J. A. (2003). Core affect and the psychological construction of emotion. Psychological Review, 110, 145-172. https://doi.org/10.1037/0033-295X.110.1.145

Schimmack, U., Schupp, J., \& Wagner, G. (2008). The influence of environment and personality on the affective and cognitive component of subjective well-being. Social Indicators Research, 89(1), 41-60. https://doi.org/10.1007/s11205-007-9230-3

Tov, W. (2018). Well-being concepts and components. In E. Diener, S. Oishi, \& L. Tay (Eds.), Handbook of well-being. Salt Lake City, UT: DEF Publishers,. Published online (doi:nobascholar.com)

Västfäll, D., Friman, M., Gärling, T., \& Kleiner, M. (2002). The measurement of core affect: A Swedish self-report measure. Scandinavian Journal of Psychology, 43, 19-31. https://doi.org/10.1111/14679450.00265

Västfäll, D., \& Gärling, T. (2007). Validation of a Swedish short self-report measure of core affect. Scandinavian Journal of Psychology, 48, 233-238. https://doi.org/10.1111/j.14679450.2007.00595.x

Whillans, A. V., Dunn, E. W., Smeets, P., Bekkers, R., \& Norton, M. I. (2017). Buying time promotes happiness. Proceedings of the National Academy of Science U S A, 114, 8523-8527. https://doi.org/10.1073/ pnas. 1706541114

Yik, M., Russell, J. A., \& Steiger, J. H. (2011). A 12-point circumplex structure of core affect. Emotion, 11, 705-731. https://doi.org/10.1037/a0023980

Publisher's Note Springer Nature remains neutral with regard to jurisdictional claims in published maps and institutional affiliations. 